\begin{tabular}{|c|c|}
\hline & $\begin{array}{l}\text { International Journal of Trend in Scientific } \\
\text { Research and Development (IJTSRD) }\end{array}$ \\
\hline 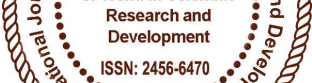 & International Open Access Journal \\
\hline 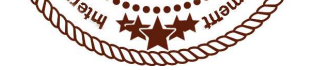 & ISSN No: 2456 - 6470 | www.ijtsrd.com | Volume - 2 | Issue - 2 \\
\hline
\end{tabular}

\title{
Feasibility Study and Entrepreneurial Success: Evidence from Selected Manufacturing Firms in Anambra State
}

\author{
Nwakoby, Nkiru Peace \\ Department of Business Administration, \\ Nnamdi Azikiwe University, Awka, Nigeria
}

\author{
Ezejiofor, Raymond A \\ Department of Accountancy, \\ Nnamdi Azikiwe University, Awka, Nigeria
}

\section{ABSTRACT}

This study assesses the extent at which manufacturing firms undertook feasibility studies prior to set up their businesses. Specifically, the study ascertained whether manufacturing firms in Anambra State ensure adequate financing; consider the existing competitors and embarked on market determination prior to their commencement. Three hypotheses were formulated in line with the objectives of the study. Survey research design was adopted. Data were obtained from questionnaires and analyzed with five point likert's scale and the three hypotheses formulated were tested using t-test statistical tool with aid of SPSS statistical package version 20.0. From the analysis, the study found that the revealed that manufacturing firms ensure adequate financing, considered the existing competitors and embarked on market determination prior to commencement. Based on the findings, the researcher recommended among others that Government should assist entrepreneurs in documenting reliable market information and ensure easy accessibility of fund, this can increasing their interest in feasibility study.

Keywords: Feasibility Study, Entrepreneurial Success and manufacturing firms

\section{Introduction}

Many researchers argued that entrepreneurship is essential for the continued dynamism of the modern market economy and that the entrance of new businesses can foster competition and economic growth (van Praag \& Versloot, 2007). Similarly, it becomes clear that entrepreneurs are the key drivers for economic development as they generate highlevels of economic growth by creating new jobs, shaping innovation, enhancing competition and increasing productivity (Acs 2004). Shane and Venkataraman (2000) characterized entrepreneurship as the process of discovery, creation, and profitable exploitation of markets for goods and services.

All businessmen are advised to know all that they are capable of knowing about the enterprise, the product or service that they want to provide and the only way of doing this is by carrying out a well prepared feasibility studies, this has to be done through the businessmen (Mohammed, 2014).

Carrying out any technical study involves planning to reduce the degree of risk in operation or organization by providing information concerning the circumstances and facts that influence success or failure of a proposed course of action. Planning is deciding in advance what, when, who and how to do carry out operations. This is a set of managerial activities designed to prepare the enterprise for the future and ensure that decisions regarding the use of people and materials assist in achieving the aims of the enterprise.

The need for firms market positioning most times become abortive due to lack of direction and reliable market information. This has crippled their competitiveness, to survive in a harsh business environment like Nigeria. In the absence of feasibility study, it may be difficult for firms to discover the 
strategic advantages they have over their environment.

Feasibility study is a means to investigate the potential outcome of a project, but most of entrepreneurs are ignorant of this before setting up a business. Though some firms has been constrained by the challenges such as lack of knowledge of technology, unfair competition, inadequate market research, poor policy implementation, which contributed to the poor development of industries in Nigeria, this has been worrisome that despite the level of accessibility of technology and government contributions towards entrepreneurship development, companies most especially in remote areas in Nigeria have not creditably performed well.

In light of this, this study intends to examine the importance of feasibility studies in enhancing the growth and development of manufacturing firms to attain efficiency in business. The study will also try to find out why feasibility studies have showed its relevance and importance in starting up business organization.

The main objective of this study is to assess the extent at which manufacturing firms in Anambra State undertook feasibility studies prior to set up their business. The specific objectives are to ascertain whether manufacturing firms ensure adequate financing, consider the existing competitors, and embark on market prior to commencement.

\section{REVIEW OF RELATED LITERATURE}

\section{Conceptual Framework}

\section{Entrepreneurship}

Number of scholars defines entrepreneurship differently. However, 'entrepreneurship is a process integrating opportunity, resources and people/the entrepreneurs', (Timmons \& Spinelli, 2009). Entrepreneurship is by no means a new concept and its origin can be traced back to the 118th century when Richard Cantillon first grouped economic agents into three categories; land, finance and wage earners and those economic agents who engage in market exchange for profit at their own risk (Diyoke, 2014).
Entrepreneurship is the most effective method for creating new enterprises, and bringing new products and services to the market. To be enterprising is to keep your eyes open and your mind active. It is to be skilled enough, confident enough, creative enough, and disciplined enough to seize opportunities that present themselves regardless of the environmental influence (Nwafor, 2007).

Soyibo (2006) sees entrepreneurship as the process of identifying an opportunity related to needssatisfaction and converting it to a product or service of value. It can also be conceptualize to mean the process and activities undertaken by entrepreneurs directed at capturing value associated with business opportunities. It can be seen as a process driven by the desire to innovate; that is producing new things (goods and services) or improving on existing ones, and profiting from it. Entrepreneurship is concerned with wealth creation through the creation of value. It involves the destruction of existing market structures by the creation of new markets (otherwise reduction in market shares of current dominating competitors) through improvement of existing products or the development of entirely new products. This is what Shumpeter cited in Soyibo (2006), called creative destruction.

Duru (2011) stresses that many people have the wrong assumption that anyone who manages a large company is an entrepreneur. These managers are not entrepreneurs because they do not have final control over the company and they do not make decisions that involve risking the company s resources.

Duru (2011) stated some basic characteristics of entrepreneurs include: Ambition; Optimism; Achievement orientation; Independent mindedness; Goal orientation; Individualism; Self-confidence; Open- mindedness and Tolerance for ambiguity. Schumpeter introduced the concept of innovation and power.

The entrepreneur dreams, invents, creates and figures out how to convert an idea or dream into a profitable reality. This is a person who demonstrates the capability to see and evaluate business opportunities, to gather the necessary resources to take advantage of them and initiates appropriate actions to ensure success. The entrepreneur is action oriented, highly motivated and takes calculated or moderate risks to achieve goals Entrepreneurship is the function of being creative and responsive within and to the 
environment. Entrepreneurship activity is a destabilizing force, which starts the process of creative destruction which is the essence of economic development.

\section{Entrepreneurs Success}

Rather than betting on the "horse" (i.e., the business idea and the business plan), they are now much more likely to bet on the "jockey" and look for someone who has a history of successful past entrepreneurial efforts. These investors have come to realize that a good business plan does not necessarily make a good business, but a good entrepreneur can, whether the business plan is optimal or not. Obviously, no one will display all of the qualities, but this worksheet can still help you assess your potential for success as an entrepreneur (Reilly \& Millikin, 2013). Being a successful entrepreneur means more than starting new ventures every other day. It means the right attitude towards a business and the determination and grit to achieve success.

A successful entrepreneur always has a strong sense of self confidence and a healthy opinion of their skills and abilities. Their personality is assertive and strong. They are always focused and do not really dilly dally with the issues at hand. This is what makes them different from the rest.

An entrepreneur should always be on the lookout for new innovations and ideas in order to emerge as a winner. They should constantly reinvent themselves and think of better ways to run a business and improvise on the products and services offered by them.

Another important quality of a successful entrepreneur is openness in adopting change. They should not be headstrong and stubborn when it comes to choosing other options. Change is the only thing that is constant in business no one can make any profits on age old methods (Wikipedia, 2017).

The path to success lies in evolution, whether it is evolution of ideas, services and products or technology. An entrepreneur should have an open mind and eagerness to learn new things. It is imperative to understand that the only way to keep at the top is to keep on changing and evolving with the time. An entrepreneur should be aware of the latest service techniques and technology in order to serve the clients in a better way.
Accepting rejection or constructive criticism can go a long way in making an entrepreneur successful. Criticism shows what he or she is not doing properly or where change is needed. However it must be remembered that accepting criticism is a very important way of getting success. This is because a person will then be aware of the shortcomings of his business and accordingly make amends. Hence accepting criticism is actually a good way of improvising.

\section{Feasibility Study}

A feasibility study is designed to provide an overview of the primary issues related to a business idea. The purpose is to identify any "make or break" issues that would prevent your business from being successful in the marketplace (Echetama, Obi \& Joel, 2016). In other words, a feasibility study determines whether the business idea makes sense. In the view of O'Brien \& Marakas (2011) a feasibility study evaluates the project's potential for success; therefore, perceived objectivity is an important factor in the credibility of the study for potential investors and lending institutions. It must therefore be conducted with an objective, unbiased approach to provide information upon which decisions can be based. Georgakellos \& Marcis (2009) posits that a well-designed feasibility study should provide a historical background of the business or project, a description of the product or service, accounting statements, details of the operations and management, marketing research and policies, financial data, legal requirements and tax obligations.

Adidu and Olaniyi (2006) opined that a good feasibility study helps to determine the viability of a proposed business and the risks associated with it, enables the entrepreneur to reject or accept a business before starting it, reveals if there is market for the proposed business and examines more on marketing requirements of the business ventures, guides the implementation of the business plan, helps in determining the sources of financing the business, reveals the machines, facilities and equipment needed for the proposed business, helps determining the number and nature of staff required for the work of the business and helps in identifying those factors that will create unusual high risks and probability of failure or loss.

Similarly, Hofstrand and Holz-Clause (2009) added 
that feasibility study gives focus to the proposed business and outline alternatives, identify new opportunities through the investigation process, identifies reasons not to proceed with the proposed business, provides documentation that the business idea was thoroughly investigated and helps attract equity investment. The feasibility study is a critical step in the business assessment process. If properly conducted, it may be the best investment ever made.

Furthermore, feasibility study is an analysis of the viability of an idea; the feasibility study focuses on helping to answer the essential question of "should we proceed with the proposed project idea (Hofstrand \& Holz-Clause (2008). A feasibility study is also a preliminary study undertaken to determine and document projects viability (Cashman \& Rosenblatt, 2006).

A basic feature of a feasibility study is that it should provide a thorough analysis of the business opportunity including a look at possible road block that may stand in the way of the co-operative success. The outcome of feasibility will indicate whether or not to proceed with the proposed venture. If the results of the feasibility study are positive, then the cooperative can proceed to develop a business plan (Mohammed, 2014).

A feasibility study helps an entrepreneur to know whether it is achieving set targets or not and where they are not being met, adjustments should be made (Nigeriabusinessinfo.com, Feb,2004). Starting a business is hardly an example of simple stimulusresponse behaviour. Entrepreneurship is clearly a process where intentionality is central (Katz \& Armhein, 1998).

Ifechukwu (2006) identified the following as the types of skills required for conducting a good feasibility study: environmental analytical skills, market analysis skill, technical analysis skills, economic analysis skills and financial analysis skills. Environmental analysis skill according to Inegbenebor (2006) is the ability to examine the business environment in terms of the legal requirements, location, social factors, government support and regulation among others. Market analysis skill is the ability to examine the target market (customers), suitability of the product for the target market, existing competitors (their strengths and weaknesses), pricing system, and product delivery and extension services among others. A well prepared feasibility study covers at least all the aspects of mentioned above although there are other areas (Echetama, Obi \& Joel, 2016).

\section{A Business Feasibility Study}

A Business Feasibility Study can be defined as a controlled process for identifying problems and opportunities, determining objectives, describing situation, defining successful outcomes and assessing the range of costs and benefits associated with several alternatives for solving a problems,. The Business Feasibility Study is used to support the decision making process based on a cost benefits analysis of the actual business or project viability (Gofton \& Ness, 1997).

\section{Importance of Feasibility Study to firms}

Feasibility study has become a very valuable tool for potential investors, industrialists, bankers, suppliers and others to ensuring that the business concept is technically, financially, socially, economically, legally and profitably sound before investing in it. It is estimated that only one in fifty business ideas are actually commercially viable. Therefore a business feasibility study is an effective way to safeguard against wastage of further investment or resources (Hoagland \& Williams, 2000). If a project is seen to be feasible from the result of study, the next logical step is to proceed with the full Business plan. A thorough and viability analysis provides an abundance of information that is also necessary for the Business plan. For example: a good market analysis is necessary in order to determine the business concept's feasibility. This information provides the basis for the market section of the Business Plan (Hoagland \& Williams, 2000).

Finally, a feasibility study should contain clear supporting evidence for its recommendations. The strength of the recommendations can be weighed against the study's ability to demonstrate the continuity that exists between the research analysis and the proposed business model (Mohammed, 2013).

\section{Components of a Feasibility Study}

The acronym TELOS is often used to capture the five areas of feasibility - Technical, Economic, Legal, Operational, and Scheduling.

Technical Feasibility: Technical feasibility seeks to evaluate the technical capabilities of the organization: Is the proposed technology or solution practical? Do 
we currently possess the necessary technology? A mature technology has a larger customer base for obtaining advice concerning problems and improvements. Is the required technology available "in house"? If the technology is available, does it have the capacity to handle the solution? If the technology is not available, can it be acquired?

This show how readily available the technology is upon the understanding of the production process. In the course of breakdown, is it possible to have the technicians to maintain them locally? What about infrastructures needed for the project? If these questions can be answered in the affirmative, then the project is technically feasible (Thompson, 2003). Wickham (2004) on the other hand states that what necessarily should be involved in technical feasibility includes the hardware and software network capability. According to O'Brien \& Marakas (2011), this assessment is based on an outline design of system requirements, to determine whether the company has the technical expertise to handle completion of the project. When writing a feasibility report, the following should be taken to consideration:

i. A brief description of the business to assess more possible factors which could affect the study

ii. The part of the business being examined

iii. The human and economic factor

iv. The possible solutions to the problem

Economic feasibility: The purpose of the economic feasibility assessment is to determine the positive economic benefits to the organization that the proposed system will provide. It includes quantification and identification of all the benefits expected. This assessment typically involves a cost/ benefits analysis.

Legal feasibility: Determines whether the proposed system conflicts with legal requirements, e.g. a data processing system must comply with the local data protection regulations.

Operational feasibility: Operational feasibility is a measure of how well a proposed system solves the problems, and takes advantage of the opportunities identified during scope definition and how it satisfies the requirements identified in the requirements analysis phase of system development (Bentley \& Whitten, 2007). Benjamin \& Wolt (2010) posits that to ensure success, desired operational outcomes must be imparted during design and development. These include such design-dependent parameters such as reliability, maintainability, supportability, usability, disposability, sustainability, affordability and others. A system may serve its intended purpose most effectively when its technical and operating characteristics are engineered into the design. Therefore, operational feasibility is a critical aspect of systems engineering that needs to be an integral part of the early design phases.

O'Brien; is of the view that an organizational feasibility should contain how well the proposed system supports the business priorities of the organization (Mohammed, 2014). According to Michele (2008), other feasibility factors include;

Schedule feasibility: A venture will fail if it takes too long to be completed before it is useful. Typically this means estimating how long the system will take to develop, and if it can be completed in a given time period using some methods like payback period. Schedule feasibility is a measure of how reasonable the venture timetable is. Given our technical expertise, are the ventures deadlines reasonable? Some ventures are initiated with specific deadlines. It is necessary to determine whether the deadlines are mandatory or desirable.

Resource feasibility: This involves questions such as how much time is available to build the new system, when it can be built, whether it interferes with normal business operations, type and amount of resources required, dependencies, and developmental procedures with company revenue prospectus.

Market and economic feasibility: Market feasibility studies typically involve testing geographic locations for a real estate development project, and usually involve parcels of real estate land. Developers often conduct market studies to determine the best location within a jurisdiction, and to test alternative land uses for given parcels. Jurisdictions often require developers to complete feasibility studies before they will approve a permit application for retail, commercial, industrial, manufacturing, housing, office or mixed-use project. Market Feasibility takes into account the importance of the business in the selected area. 


\section{Empirical Studies}

Echetama, Obi and Joel (2016) effect of feasibility study on the growth of SMES in Imo-State. The study took a descriptive survey approach and relied on a five point likert scale questionnaire as its major source of data. 9 SMEs were randomly selected from Owerri Zone of Imo State. A sample of 30 top management staff members was obtained by employing the purposive sampling technique. The data gathered was analyzed using one sample t-test with the aid of 20.0 version of the statistical package for social sciences (SPSS 20.0). Results obtained from the study shows a p-value (sig.2-tailed) of 0.000 and 0.000 in the two hypotheses, which implies that the $\mathrm{t}$-calculated is lesser than t-tabulated (i.e $0.000<0.05$ ). They rejected the two null hypotheses. Based on the results obtained it concludes that Feasibility study is a meaningful management tool in advancing the growth and performance of SMEs.

Mohammed (2014) examines the impact of feasibility study in enhancing growth and development of business organizations in Nigeria. It was proven that a well-planned feasibility studies enables the business owner to understand the schematics of the venture and boost confidence in facing challenges that may arise in the business life circle because the target, through feasibility study has been attained; howbeit abstract. A man who knows where he is going arrives there no matter the obstacles. The work concluded that feasibility study impact significantly on the growth of a business and reduces the level of exposure to risk and ensures success.

Adegbite, Ilori, Irefin, and Abereijo, Aderemi (2006) evaluated the impact of entrepreneurial characteristics on the performance of small-scale manufacturing industries in Nigeria. This is with a view to identifying these entrepreneurial characteristics and the factors that influence their translation to optimum business performance. Primary data, through structured questionnaire, were collected from the samples of 100 firms randomly selected from among the small-scale manufacturing industries engaged in food and beverage; textile and wearing apparel; wood and wood products; chemical and pharmaceuticals; and fabricated metal products. Data were analyzed using descriptive and inferential statistics with the aid of Statistical Packages for Social Scientists (SPSS). Also, the correlation analysis and regression analysis were carried out to examine the relationship between contextual variables and business performance. The results showed that human resource factors and the sales revenue were found to be inadequate and severely inhibited the potential of the entrepreneurs for performance and growth.

Dissanayake (2013) Due to the proven validity of intention based models to assess entrepreneurial intention and the non-validity of assessing entrepreneurial intention based on psychological characteristics, general dispositions, and personality traits and demographic factors, the researcher investigates the most appropriate model specification to assess entrepreneurial intention which is named as Krueger and Brazeal's Entrepreneurial Potential Model. Particularly, the study was conducted in the University of Kelaniya, Sri Lanka, among the undergraduates of the Department of Commerce and Financial Management. Multiple regression analysis of the study was used to prove the stated hypothesis of the study and the researcher concludes that behavioral beliefs, self-efficacy and credibility affect significantly towards the entrepreneurial intention within the selected undergraduates.

Zoi (2013) analyze the influence of perceptions of feasibility and desirability towards entrepreneurship on entrepreneurial intentions and investigate whether differences exist between southern and northern European countries. Data is taken from 1Flash Eurobarometer Survey (No 283), conducted on December 2009 and January 2010. A total of 22156 respondents in 32 countries consist our sample. Results suggest that the effect of perceived selfefficacy on self-employment intentions is higher for individuals residing in southern European countries. On the contrary, it was found that perceived desirability influences in a greater extent individuals' self-employment intentions' in northern European countries. The findings of this study should be taken into consideration by policy makers in southern European countries who have to increase perceptions of desirability. The paper contributes both to the cognitive theory literature and to the empirical literature which assesses the impact of perceptions at a country level.

Alireza and Behnaz (2015) investigate the effect of technical factors, human factors as well as the moderating effect of organizational culture on implementing business process reengineering in Iran Air. Research method of this study is applied in terms of its objective and it is descriptive-survey in terms of its method. The statistical population of the study 
included senior managers, middle managers, operational managers and supervisors and their total number was 312. The results of the analysis of statistical data show that human factors and technical factors affect the implementation of business process reengineering in Iran Air. Organizational culture also moderates the effect of human factors on the implementation of business process reengineering in Iran Air.

Zahra (2011) identify the main causes of business failure based on an empirical study in Iran. This empirical study on the sample of failed business owners/ managers pointed out that the main causes of business failure are due to lack of good management, no support from banks and financial institutions, inadequate economic sphere, and insufficient governmental policies. In addition, this study indicates differences in some causes of business failure influenced by gender and business sector.

Anietie (2012) investigated the issues and challenges to the growth of entrepreneurship in the Niger Delta region of Nigeria. Based on the findings, Anietie concludes that entrepreneurship in the Niger Delta region is at its lowest ebb. In other words, a number of practicing and the would be entrepreneurs are faced with great difficulties in their entrepreneurial pursuit. These difficulties are occasioned by poor state of infrastructure, difficulty in accessing finance, sociocultural factors such as superstitious believes and ignorance.

Agu and Ayogu (2015) study was carried out primarily through the survey method and interview of entrepreneurs in the Agricultural sector at three locations namely Igbariam, Awka and Abakiliki. Secondary data were obtained through books, journals, and internet. The study had population size of 686 out of which a sample size of 230 was realized using Taro Yamane formula at 5\% error tolerance and $95 \%$ level of confidence. Instrument used for data collection was primarily questionnaire and interview. 230 copies of the questionnaire were distributed while 208 copies were returned. The survey research design was adopted for the study. Chi-Square statistical tool was used to test the three hypotheses using SPSS. Findings indicate that multiple taxes and levies, lack of knowledge of technology and unfair competition are the Challenges of entrepreneurship development in Nigeria; Technology enhances entrepreneurship development in Nigeria through improved customer satisfaction and reduction in transaction time;
Provision of technical support and research center are the contributions of government towards entrepreneurial development in Nigeria.

Ezejiofor, Olise, Ezenyirimba and Otugo (2014) examine the appraisal of Entrepreneurship and Small and Medium Enterprises (SME) on Sustainable Economic Growth in Nigeria. Survey research design was adopted. Data obtained were analyzed with means and standard deviation. Z-test statistical technique was used to test whether Entrepreneurship and SME as a profitable venture enhanced sustainable economic growth in Nigeria. The paper found that entrepreneurship has contributed significantly to enhance sustainable economic growth of Nigeria through mobilization of individual savings and channeling of such in productive investment as a major source of domestic capital formation in economy. Consequently, it is recommended among others that there should be policies that will emphasis more on technical education at all levels, for the training and development of human capital capacity building across the country.

Diyoke (2014) point out that entrepreneurship development in Nigeria is very slow despite all the numerous programme and schemes that have been designed by different government at different times. Descriptive survey research method was used in this study whereby data collected from both primary and secondary sources were analyzed using percentages and mean scores, while the hypothesis were tested with Chi-square. The result indicated that apart from the known problems of inadequate capital and lack of competent and skilled management, there are other challenges that hinder entrepreneurial activities in the economy. The Nigerian business environment is facing a lot of problems as a result of epileptic power supply, violent clashes of militant groups, kidnapping, looting, arson, and so on. The study concludes among others that with the introduction of business incubators into the system, proper handling of political and social economic problems, privatization and commercialization of power sector and provision of alternative source of power supply, entrepreneurship development has a lot of prospects in the country.

\section{METHODOLOGY}

\section{Research Design}

Survey research was adopted for the study. According to Nworgu (2004), this design involves the gathering 
of data through questions and interviews from few people or items considered to be representative of the entire group. This design was selected for this study because the study seeks to sample the opinion of respondents and draw inferences based on their views.

\section{Population and Sample Size of the Study}

The population of the study consists of the 156 of manufacturing firms operating in Anambra State, Nigeria. The sample procedure in this study is predicted on the assumption of randomness, normality and representativeness.

\section{Method of Data Analysis}

The data that was collected for the study was presented and analyzed; the formulated hypotheses were tested using parametric analysis of one sample ttest with aid of SPSS Version 20.0

\section{DATA PRESENTATION AND INTERPRETATION}

From table I above, out of 156 copies of questionnaires was distributed, and 108 were returned, this represent $69 \%$.

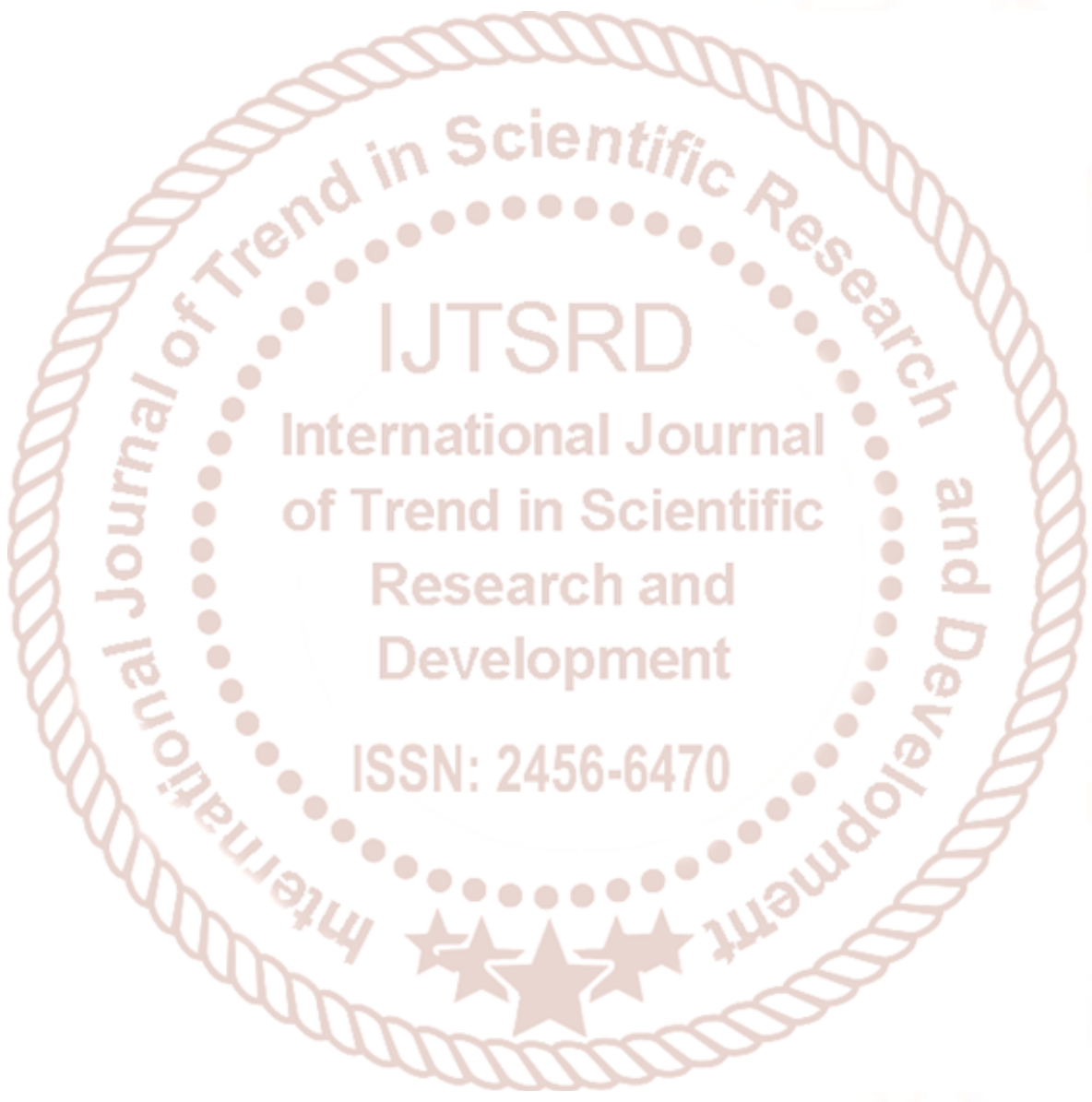


International Journal of Trend in Scientific Research and Development (IJTSRD) ISSN: 2456-6470

\section{Data Presentation}

Table 4.2.1: Summary of responses using five point Likert's scale

\begin{tabular}{|c|c|c|c|c|c|c|}
\hline $\mathbf{S} / \mathbf{N}$ & Questionnaire & SA & A & $\mathrm{U}$ & D & SD \\
\hline 1 & $\begin{array}{l}\text { Manufacturing industries ensure adequate source of financing their } \\
\text { business prior to commencement. }\end{array}$ & 48 & 45 & 5 & 10 & 0 \\
\hline 2 & $\begin{array}{l}\text { Most of manufacturing industries plan for how capital based of their } \\
\text { business before setting up the business. }\end{array}$ & 50 & 43 & 5 & 8 & 4 \\
\hline 3 & $\begin{array}{l}\text { The issue of funding has been the major thing why planning for } \\
\text { establishment of business enterprise. }\end{array}$ & 40 & 43 & 3 & 17 & 5 \\
\hline 4 & $\begin{array}{l}\text { The provision of adequate source of capital is a means of business } \\
\text { survival. }\end{array}$ & 39 & 49 & 5 & 13 & 2 \\
\hline 5 & $\begin{array}{l}\text { Thinking of other manufacturing industries with similar production is } \\
\text { given priority in setting up a manufacturing industry. }\end{array}$ & 57 & 40 & 4 & 7 & 0 \\
\hline 6 & $\begin{array}{l}\text { The feasibility study on the existing competitors prior to commencement } \\
\text { gives room for branding and packaging. }\end{array}$ & 35 & 52 & 5 & 19 & 0 \\
\hline 7 & $\begin{array}{l}\text { Manufacturing industries consider the existing competitors in other to } \\
\text { ensure a successful production process. }\end{array}$ & 45 & 39 & 4 & 16 & 4 \\
\hline 8 & $\begin{array}{l}\text { Feasibility study on the existing competitors prior to commencement } \\
\text { helps in location of the business for a successful venture. }\end{array}$ & 46 & 51 & 0 & 10 & 1 \\
\hline 9 & $\begin{array}{l}\text { Manufacturing industries embarked on nearest of market prior to } \\
\text { commencement of their operation. }\end{array}$ & 41 & 58 & 0 & 9 & 2 \\
\hline 10 & $\begin{array}{l}\text { Feasibility study on the market/advertising is given a priority to the } \\
\text { commencement of manufacturing industries. }\end{array}$ & 49 & 54 & 3 & 1 & 1 \\
\hline 11 & $\begin{array}{l}\text { Manufacturing industries plan for the location of the business how to } \\
\text { distribute their products in order to make them available to the consumers. }\end{array}$ & 38 & 50 & 2 & 6 & 2 \\
\hline 12 & $\begin{array}{l}\text { Plan for the location of the business how to distribute their products in } \\
\text { order to make them available to the consumers. }\end{array}$ & 35 & 63 & 0 & 7 & 3 \\
\hline
\end{tabular}

Source: Field Survey 2018

\section{Test of Hypotheses}

\section{Hypothesis 1}

$\mathrm{Ho}_{1}$ : Manufacturing firms do not ensure adequate financing prior to commencement.

\begin{tabular}{|c|c|c|c|c|c|c|}
\hline \multicolumn{7}{|c|}{ One-Sample Test } \\
\hline \multirow[t]{3}{*}{ Questions } & \multicolumn{6}{|c|}{ Test Value $=0$} \\
\hline & \multirow[t]{2}{*}{$\mathrm{t}$} & \multirow[t]{2}{*}{ Df } & \multirow[t]{2}{*}{$\begin{array}{c}\text { Sig. } \\
\text { (2-tailed) }\end{array}$} & \multirow[t]{2}{*}{$\begin{array}{c}\text { Mean } \\
\text { Difference }\end{array}$} & \multicolumn{2}{|c|}{$\begin{array}{l}95 \% \text { Confidence Interval of the } \\
\text { Difference }\end{array}$} \\
\hline & & & & & Lower & Upper \\
\hline 1 & 2.097 & 4 & .104 & 21.60000 & -6.9933 & 50.1933 \\
\hline 2 & 2.182 & 4 & .095 & 22.00000 & -5.9995 & 49.9995 \\
\hline 3 & 2.546 & 4 & .064 & 21.60000 & -1.9524 & 45.1524 \\
\hline 4 & 2.285 & 4 & .084 & 21.60000 & -4.6459 & 47.8459 \\
\hline
\end{tabular}

From the above one sample t-test table, the five questions give a positive result. The calculated t-value is 9.110 while the table $\mathrm{t}$-value is 1.812. This means that calculated $\mathrm{t}$-value if greater than the table t-value 
(9.110>1.812). We therefore reject null hypothesis and uphold alternative hypothesis which states that manufacturing firms ensure adequate financing prior to their commencement.

\section{Hypothesis 2}

$\mathrm{Ho}_{2}$ : Manufacturing firms does not consider the existing competitors prior to their commencement.

\begin{tabular}{|c|c|c|c|c|c|c|}
\hline \multicolumn{7}{|c|}{ One-Sample Test } \\
\hline \multirow[t]{3}{*}{ Questions } & \multicolumn{6}{|c|}{ Test Value $=0$} \\
\hline & \multirow[t]{2}{*}{$\mathrm{t}$} & \multirow[t]{2}{*}{ df } & \multirow[t]{2}{*}{$\begin{array}{c}\text { Sig. } \\
\text { (2-tailed) }\end{array}$} & \multirow[t]{2}{*}{$\begin{array}{c}\text { Mean } \\
\text { Difference }\end{array}$} & \multicolumn{2}{|c|}{$\begin{array}{l}\text { 95\% Confidence Interval of the } \\
\text { Difference }\end{array}$} \\
\hline & & & & & Lower & Upper \\
\hline 5 & 1.901 & 4 & .130 & 21.60000 & -9.9417 & 53.1417 \\
\hline 6 & 2.308 & 4 & .082 & 22.20000 & -4.5088 & 48.9088 \\
\hline 7 & 1.931 & 4 & .126 & 17.80000 & -7.7885 & 43.3885 \\
\hline 8 & 1.904 & 4 & .130 & 21.40000 & -9.8100 & 52.6100 \\
\hline
\end{tabular}

From the above one sample t-test table, the five questions give a positive result. The calculated t-value is 8.044 while the table $\mathrm{t}$-value is 1.812 . This means that calculated $\mathrm{t}$-value if greater than the table t-value $(8.044>1.812)$. We therefore reject null hypothesis and uphold alternative hypothesis which states that manufacturing firms consider the existing competitors prior to their commencement.

\section{Hypothesis 3}

Ho: Manufacturing firms do not embark on market determination prior to their commencement.

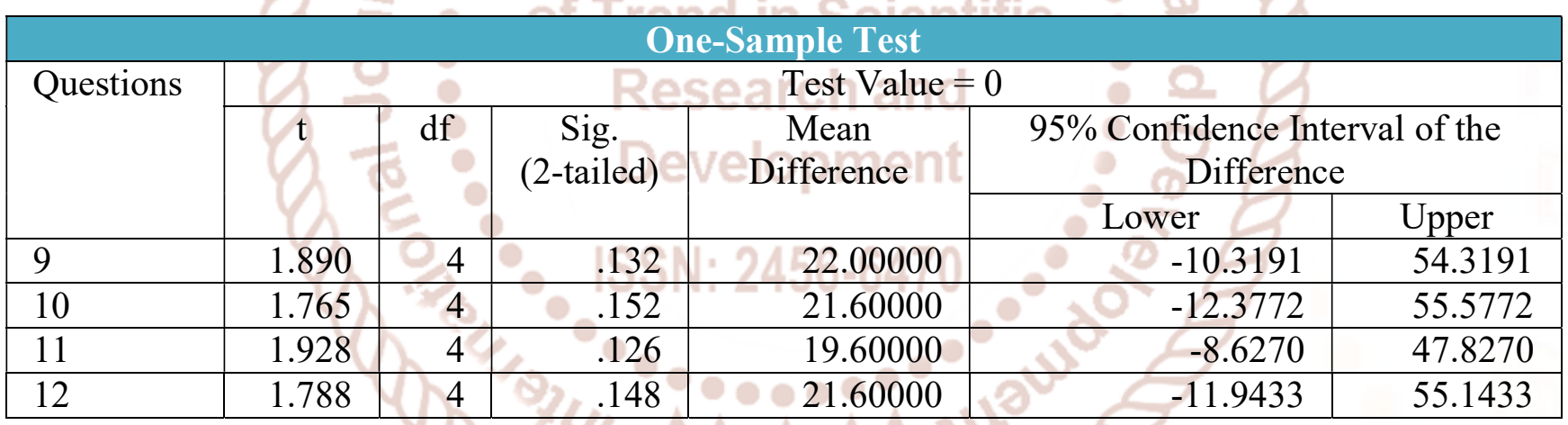

From the above one sample t-test table, the five questions give a positive result. The calculated t-value is 7.371 while the table $t$-value is 1.812 . This means that calculated $t$-value if greater than the table t-value (7.371>1.812). We therefore reject null hypothesis and uphold alternative hypothesis which states that manufacturing firms embarked on market determination prior to their commencement.

\section{Discussion of Findings}

From the analysis result, the study revealed that manufacturing firms ensure adequate financing; considered the existing competitors and embark on market determination prior to commencement.

This result is in line with Mohammed (2014) whose work concluded that feasibility study impact significantly on the growth of a business and reduces the level of exposure to risk and ensures success.
Also, Zahra (2011) indicates differences in some causes of business failure influenced by gender and business sector. In other hand, Anietie (2012) found that entrepreneurs are faced with great difficulties in their entrepreneurial pursuit. Based on the study, these difficulties are occasioned by poor state of infrastructure, difficulty in accessing finance, sociocultural factors such as superstitious believes and ignorance. 
CONCLUSION AND RECOMMENDATIONS

\section{Conclusion}

Based on data being presented and analyzed in the process of this study, it can be concluded that feasibility study has an impact in enhancing the growth and development of business organizations in Nigeria because a greater fraction of responses from respondents were positive on the impact of feasibility study at every stage of their business. The revealed that manufacturing firms ensure adequate financing prior to commencement, consider the existing competitors prior to commencement, embark on market determination prior to commencement.

\section{Recommendations}

Based on the result of this study, the researcher recommended the followings;

1. Government should assist entrepreneurs in documenting reliable market information and ensure easy accessibility of fund, this can increasing their interest in feasibility study.

2. In order to identify the changing trends and update their feasibility report as supposed, firm's managers should engage in constant environmental surveillance.

3. Services of professionals should be engaged to draw up a detailed plan for the entrepreneur due to their vast experience in this field rather than doing it themselves.

\section{References}

1) Adegbite, S.A. Ilori, M.O. Irefin, I.A. Abereijo, I.O \& Aderemi, H.O.S., (2006). Evaluation of the impact of entrepreneurial characteristics on the performance of small scale manufacturing industries in Nigeria Journal of Asia Entrepreneurship and Sustainability.111(1)

2) Ajzen, I. (1991). The Theory of Planned Behavior. Organizational Behavior And Human Decision Processes , 50, 179-211.

3) Acs, Z., Audretsch, D., Braunerhjelm, P., \& Carlsson, B. (2004). "The missing link: The knowledge filter and entrepreneurship in endogenous growth", CEPR Discussion Paper,478.

4) Acs, Z.J. \& Audretsch, D.B. (1993), Small firms and entrepreneurship: an East-West perspective, Cambridge University Press.

5) Agu, E. O. \& Ayogu, D. U. (2015). Assessing the Prospects and Problems of Entrepreneurship Development in Nigeria. International Journal current research and academic review ISSN: 2347-3215 Volume 3 Number 10 (October-2015) pp. 208-221.

6) Alireza, O., \& Behnaz, K. (2015). Factors affecting the implementation of business process reengineering: taking into account the moderating role of organizational culture(Case Study: Iran Air) International Conference on Applied Economics and Business, ICAEB 2015

7) Bird, B. (2008). Implementing entrepreneurial ideas: the case for intentions. Academy of Management Review, Vol. 33 No. 2, pp. 328-40.

8) Crant, M. J. (1996). The proactive personality scale as a predictor of entrepreneurial intentions. Journal of Small Business Management , 34(3), $42-49$.

9) Cashman \&Rosenblatt (2006). System Analysis and Design. www.wikipedia.org

10) Drucker P. F. (1985). Innovations \& Entrepreneurships. New York, Harper Trade.

11) Diyoke, C. I. (2014). Entrepreneurship development in nigeria: issues, problems and prospects. International Journal of Technical Research and Applications e-ISSN: 2320-8163, www.ijtra.com Special Issue 10 (Nov-Dec 2014), PP. 19-23

12) Duru, M. (2011). Entrepreneurship opportunities and challenges in Nigeria. J. Business, 1(1).

13) Drucker, P. (1985). Innovation and entrepreneurship practice and principles. Henemann U.K.

14) Davidsson, P. (1995). Determinants of entrepreneurial intentions. RENT IX Workshop in Entrepreneurship Research, Piacenza, Italy.

15) Echetama, F. C., Obi, C., \& Joel, A.-D. (2016). Effect of feasibility study on the growth of SMEs in Imo-State: a study of selected SMEs in Owerri Zone. International Journal for Research in 
Business, Management and Accounting 104 VOL 2 ISSUE 2 February 2016 Paper 10

16) Engle, L. R., Dimitriadi, N., Gavidia, J. V., Schlaegel, C., Delanoe, S., Alvarado, I., et al. (2010). Entrepreneurial intent: A twelve-country evaluation of Ajzen's model of planned behavior. International Journal of Entrepreneurial Behaviour \& Research, Vol. 16 Iss: 1 pp. 35 - 57.

17) Ezejiofor, R. A.., Olise, M, C., Ezenyirimba E., Otugo N.E.(2014). The appraisal of Entrepreneurship and SME on Sustainable Economic Growth in Nigeria. Scholars Journal of Economics, Business and Management. 1(8):367372

18) Giagtzi, Z (2013). How perceived feasibility and desirability of entrepreneurship influence entrepreneurial intentions: A comparison between southern and northern European countries.

19) Gorman, G., Hanlon, D., \& King, W. (1997). Some Research Perspectives on Entrepreneurship Education, Enterprise Education and Education for Small Business Management: A Ten-Year Literature Review. International Small Business Journal , 15(3):56-78.

20) Guerrero, M., Rialp, J., \& Urbano, D. (2006). The impact of desirability and feasibility on entrepreneurial intentions: A structural equation model. International Entrepreneurship Management Journal, 35-50.

21) Gofton L. \& Ness, M. (1997) business market research, kogan page London pp 165

22) Hisrich p. \& Venkatraman (2002) Small and Medium Scale Enterprises and Funding in Nigeria. Nigeriabusinessinfo.com.

23) Hoagl, H.s. \&Williamson L. (2000). Feasibility Studies, Kentucky, University of Kentucky.

24) Hoagland \& Williamson http://www.uky.edu/agecon/pub/ext(2000). other/feasibilitystudy.pdf

25) Kumara, S. (2012, March). Undergraduates' Intention Towards Entrepreneurship: Empirical Evidence From Sri Lanka. pp. Vol. 20, No. 1. 105-118.

26) Kirzner, I. (1979), Perception, opportunity and profit, Chicago, IL: University of Chicago Press.
27) Krueger, N., Reilly, M., \& Carsrud, A. (2000). Competing models of entrepreneurial intentions. Journal of Business Venturing , 15, 5-6, 411-432.

28) Kruger, N. (2008). The Impact of Prior Entrepreneurial Exposure on Perceptions of New venture Feasibility and Desirability. Journal Article Excerpt.www.wikipedia.org

29) Katz J. A \& Armhein, D.G (1998). Cash flow as a factor in the mortality risk of a Business Paper Presented at the International Council of Small Business, Singapore.

30) Mohammed , A. A. (2014). The Impact of Feasibility Study in Enhancing Growth and Development of Business Organizations in Nigeria. IOSR Journal of Business and Management (IOSR-JBM) e-ISSN: 2278-487X, pISSN: 2319-7668. Volume 16, Issue 6. Ver. I (Jun. 2014), PP 32-38 www.iosrjournals.org

31) Nwafor, P.Z. 2007. Practical Approach to entrepreneurship: small and medium scale enterprises (SMEs). J. Business, (www.scirp.org/journal/PaperDownloa d.aspx?paperID=8063)

32) Nimalathasan, B., \& Achchuthan, S. (2012). Entrepreneurial Motivation and Self Employment Intention: A Case Study on Management Undergraduates of University of Jaffna. International Conference on Business and Information (ICBI) (pp. 77-90). Kelaniya: University of Kelaniya.

33) Nigeriabusinessinfo.com (2004). Prospects of Nigerian Small and Medium Scale Enterprises under the Small and Medium Industries Investment Scheme (SMIES).

34) Perera, Q. (2012, May 06). Local universities producing less than 5\% of SL's entrepreneurs. Retrieved December 25, 2012, from The Sunday Times:

http://www.sundaytimes.lk/120506/BusinessTime $\underline{\mathrm{s} / \mathrm{bt} 16 . \mathrm{html}}$

35) Peterman, N. E., \& Kennedy, J. (2003). Enterprise education: Influencing students' perceptions of entrepreneurship. Entrepreneurship Theory and Practice , 129-144.

36) Shapero, A. (1975). The displaced, uncomfortable entrepreneur. Psychology Today, Vol. 9 No. 11 pp. 83-8. 
37) Shane, S. \& Venkataraman, S. (2000), "The Promise of Entrepreneurship as a Field of Fesearch", Academy of Management Review, 25(1), 217-226.

38) Shane, S. (2000), "Prior knowledge and the discovery of entrepreneurial opportunities", Organization Science, 11(4), 448-469.

39) Shapero, A. (1975). The displaced, uncomfortable entrepreneur. Psychology Today, 9(11) pp. 83-8.

40) Singh, I., Prasad, T., \& Raut, D. R. (2012). Entrepreneurial Intent - A Review of Literature. Ninth AIMS International Conference on Management, (pp. 201-207).

41) Soyibo, A. 2006. The concept of entrepreneurship. J. Business Org. Dev., 1(5).

42) Thrikawala, S. S. (2011). The Determinants of Entrepreneurial Intention among Academics in $\mathrm{Srl}$ Lanka. International Conference on Economics and Finance Research (pp. 454-458). Singapore: IACSIT Press.
43) Timmons, J. A., \& Spinelli, S. (2009). New Venture Creation: Entrepreneurship for the 21st Century. 8th edition: McGraw-Hill.

44) Van Praag, C. M. \& Versloot, P. H. (2007), "What is the value of entrepreneurship? A review of recent research", Small Business Economics, 29(4), 351-382.

45) Veciana, J. M., Aponte, M., \& Urbano, D. (2005). University students' attitudes towards entrepreneurship: A two countries comparison. International Entrepreneurship and Management Journal, 165-182.

46) Wang, W., Lu, W., \& Millington, J. K. (2011). Determinants of Entrepreneurial Intention among College Students in China and USA. Journal of Global Entrepreneurship Research ,35-44.

47) Zahra A. (2011). An empirical study on the causes of business failure in Iranian context. African Journal of Business Management Vol. 5(17), pp. 7488-7498, 4 September, 2011. 